\title{
Supramolecular complex sacubitril/valsartan - the first representative of a new class of drugs for the treatment of chronic heart failure
}

\author{
T. V. Ashcheulova ${ }^{A-F}$, K. M. Kompaniiets ${ }^{\star A-F}$, N. M. Herasymchuk ${ }^{A-F}$
}

Kharkiv National Medical University, Ukraine

A - research concept and design; B - collection and/or assembly of data; C - data analysis and interpretation; D - writing the article; $\mathrm{E}$ - critical revision of the article; $\mathrm{F}$ - final approval of the article

Key words: chronic heart failure, sacubitril/ valsartan, left ventricular ejection fraction, natriuretic peptide, neutral endopeptidase.

Pathologia 2019; 16 (3), 408-416 DOI:

10.14739/2310-1237. 2019.3.188964

*E-mail: 05021104saga@ gmail.com

Ключові слова: хронічна серцева недостатність, сакубітрик/ валсартан, фракція викиду мівого шлуночка, натрійуретичний пептиА, нейтральна ендопептиАаза.

Патологія. - 2019. T. 16, № 3(47). -

C. $408-416$

Ключевые слова: хроническая сердечная недостаточность, сакубитрил/валсартан, фракция выброса мевого желудочка, натрийуретический пептиА, нейтральная эндопептидаза.

Патология. - 2019. -

T. 16, № 3(47). -

C. $408-416$
The average prevalence of chronic heart failure in the adult population, according to the statistics of different countries, ranges from $1.5 \%$ to $5.5 \%$ and therefore the study of this problem and of finding new approaches to the treatment of chronic heart failure is also still relevant at present.

Objective is to show an innovative strategy in the treatment of chronic heart failure, to show the benefits of using the combined drug sacubitril/valsartan (LCZ696) in comparison with the group of the mentioned above drugs for treating patients with chronic heart failure and a reduced left ventricular ejection fraction, according to the results of a large randomized clinical research, based on its biochemical properties.

Conclusions. The main positive effects of sacubitril and valsartan in patients with chronic heart failure are associated with an increase in the amount of the natriuretic peptide and the simultaneous suppression by valsartan of the negative effects of angiotensin II. The indication for the use of the sakubitril / valsartan complex is chronic heart failure (II - IV FC according to the NYHA classification) in patients with systolic dysfunction in order to reduce the risk of cardiovascular mortality and hospitalization for heart failure.

\section{Наамолекулярний комплекс сакубітрил/валсартан -} перший представник нового класу препаратів Аля Аікування хронічної серцевої недостатності

\section{Т. В. Ащеулова, К. М. Компанієць, Н. М. Герасимчук}

Середній показник поширеності хронічної серцевої недостатності серед дорослого населення, за даними різних країн, становить від 1,5 \% до 5,5 \%, тому актуальним є вивчення цієї проблеми та пошук нових підходів терапії хронічної серцевої недостатності.

Мета роботи - показати інноваційну стратегію в лікуванні хронічної серцевої недостатності, переваги застосування комбінованого препарату сакубітрил/валсартан (LCZ696) порівняно з групою препаратів для лікування пацієнтів із хронічною серцевою недостатністю, зниженою фракцією викиду лівого шлуночка, за результатами великих рандомізованих клінічних досліджень, ґрунтуючись на його біохімічних властивостях.

Висновки. Основні позитивні ефекти сакубітрилу та валсартану в пацієнтів із хронічною серцевою недостатністю пов'язані зі збільшенням кількості натрійуретичного пептиду та одночасним пригніченням валсартаном негативних ефектів ангіотензину II. Показанням для застосування комплексу сакубітрил/валсартан є хронічна серцева недостатність (II-IV ФК за класифікацією NYHA) в пацієнтів із систолічною дисфрункцією для зниження ризику серцево-судинної смертності та госпіталізації з приводу серцевої недостатності.

\section{Надмолекулярный комплекс сакубитрил/валсартан - первый представитель нового киасса препаратов Аля лечения хронической сердечной недостаточности}

\section{Т. В. Ащеулова, К. Н. Компаниец, Н. Н. Герасимчук}

Средний показатель распространенности хронической сердечной недостаточности среди взрослого населения, по данным разных стран, составляет от 1,5 \% до 5,5 \%, поэтому актуальным остается изучение этой проблемы и поиск новых подходов терапии хронической сердечной недостаточности.

Цель работы - показать инновационную стратегию в лечении хронической сердечной недостаточности, показать преимущества применения комбинированного препарата сакубитрил / валсартан (LCZ696) в сравнении с группой препаратов для лечения пациентов с сердечной недостаточностью и сниженной фрракцией выброса левого желудочка, по результатам крупных рандомизированных клинических исследований, основываясь на его биохимических свойствах.

Выводы. Основные положительные эфффекты сакубитрила и валсартана у пациентов с хронической сердечной недостаточностью связаны с увеличением количества натрийуретического пептида и одновременным подавлением валсартаном негативных эффректов ангиотензина II. Показанием для применения комплекса сакубитрил/валсартан является хроническая сердечная недостаточность (II-IV ФК по классификации NYHA) у пациентов с систолической дисфункцией с целью снижения риска сердечно-сосудистой смертности и госпитализации по поводу сердечной недостаточности. 
Chronic heart failure (CHF) is a pathological condition where the heart, due to impaired pumping function, cannot provide organs and tissues with the necessary amount of blood in accordance with the metabolic needs of the tissues.

From a clinical point of view, CHF is a syndrome, the typical features of which are a decrease in exercise tolerance, fluid retention, progressive nature and a limited life expectancy.

The average prevalence of $\mathrm{CHF}$ in the adult population, according to the statistics of different countries, ranges from $1.5 \%$ to $5.5 \%$ (these fluctuations may, in particular, be associated with the lack of unified international epidemiological criteria for $\mathrm{CHF}$ ). With age, $\mathrm{CHF}$ is progressively increasing, accounting for $10 \%$ or more of those over 70 years old.

The incidence (the number of cases of newly diagnosed $\mathrm{CHF}$ during the year in the population) ranges from 150 to 500 cases per 100 thousand people (0.15-0.50\%), moreover among people over 45 years old, this figure doubles every 10 years. Thus, given the high prevalence of CHF in the examined patients, the study of this problem continues to be relevant at present. Despite the results achieved, the problem of finding new approaches to the treatment of $\mathrm{CHF}$ is also still relevant (Heart Disease and Stroke Statistics, 2016).

At least half of patients with CHF have a reduced left ventricular ejection fraction (LVEF).

The rest of the patients are patients with preserved LVEF EF. Among the latter, in comparison with patients with reduced LVEF, a greater proportion is women, people with arterial hypertension $(\mathrm{AH})$, obesity and atrial fibrillation (AF).

Ischemic heart disease (CHD), which, according to epidemiological and multicenter clinical studies, is diagnosed in $60-75 \%$ of these patients, is considered to be the most frequent etiological cause of heart failure (HF) in Europe and the USA. There are good reasons to believe that systemic hypertension takes the second place among the etiological factors of heart failure, however, the frequent combination of coronary artery disease and hypertension makes it difficult to assess the true role of the latter in the onset of CHF. According to statistical and epidemiological data, $\mathrm{CHD}$ and $\mathrm{AH}$ (separately or in combination) cause the occurrence of $75-80 \%$ of all cases of HF [1]. The relevance of inadequately treated hypertension, as the etiological factor of CHF for Ukraine, may be indicated by data from the first national CHF statistics test conducted in 2011 (2.800 patients). Given the results obtained, $86 \%$ of outpatients with this syndrome have a diagnosis of hypertension, which in almost $2 / 3$ of cases is not controlled [2]. Old myocardial infarction (MI) is the most powerful independent risk factor for developing CHF in both the general population and among patients with hypertension. A significant risk factor for the development of CHF is also type 2 diabetes mellitus (DM). Other causes of CHF include dilated cardiomyopathy (DCM) and valvular heart disease, other causes of heart failure in developed countries account for no more than $5 \%$ of cases $[2,3]$.

The prognosis of patients with clinical manifestations of CHF is very serious; more than half of these patients die within the next 5 years. The higher the degree of $\mathrm{CHF}$ clinical severity, the worse is its clinical prognosis. Thus, the mortality rate during one year in patients with I-II FC NYHA is $6-10 \%$, increasing to $25-50 \%$ in patients with severe (IV FC NYHA) CHF. Patients with symptomatic CHF and preserved LVEF (>40 \%) are characterized by better survival (approximately double, according to 5-year follow-up) compared to patients with $\mathrm{CHF}$ and reduced LVEF.

In large placebo-controlled clinical studies it has been proved that prolonged blockade of the renin-angiotensin, sympathoadrenal systems (SAS) and aldosterone via their pharmacological antagonists - ACE inhibitors (ACEI) or angiotensin receptor blockers (ARBs), beta-blockers (BB), antagonists mineralocorticoid receptors (AMR) can slow the progression of $L V$ remodeling and systemic changes in $\mathrm{CHF}$, resulting in a reduction or elimination of its clinical symptoms and an increase in life expectancy of patients.

The introduction of modern standards of CHF pharmacotherapy along with the improvement of the medical care system for such patients enables to decrease the number of their hospitalizations for circulatory decompensation by $30-50 \%$, as well as to improve their survival rate, although to a lesser extent.

\section{Aim}

The objective of this work is to show an innovative strategy in the treatment of CHF, to show the benefits of using the combined drug sacubitril / valsartan (LCZ696) in comparison with the group of the mentioned above drugs for treating patients with CHF and a reduced LVEF, according to the results of a large randomized clinical research, based on its biochemical properties.

Heart failure - a complication of a variety of diseases and comorbid pathologies. To date, there are three groups of drugs that have a positive effect on the prognosis of patient survival. These are angiotensin-converting enzyme inhibitors (ACE inhibitors) (adding them to diuretic and digoxin enabled us to increase this figure by $17 \%$ and reduce the number of hospitalizations by $30 \%$. The next breakthrough was the introduction of $\beta$-adrenergic blockers (BAB) with an improved forecast by $35 \%$ and then the use of mineralocorticoid receptor antagonists (MRA) or aldosterone by another $30 \%$ [4]. Thus, the use of three groups of drugs improved the twoyear prognosis of patient survival by $50 \%$ and reduced hospitalization risk by $64 \%$.

Treatment of CHF as a syndrome cannot be fully effective, because HF is a complication that occurs against the background of a number of diseases, comorbid pathologies. There are a number of associated conditions that can cause HF, others cause exacerbation, decompensation. But there are also comorbid, concomitant conditions that make it difficult to treat patients. These are most often depression, Alzheimer's disease, dementia. Also, there are diseases, the symptoms of which are often perceived as CHF. They need to be identified, eliminated and only then to talk about the presence of $\mathrm{HF}$ in a patient. The most frequent causes of $\mathrm{CHF}$ are $\mathrm{CHD}$ and $\mathrm{AH}$. According to the UNIVERS study, which included 2.800 patients from 35 cities of Ukraine, ischemic heart disease (with / 
Table 1. Selected Potential Causes of Elevated Natriuretic Peptide Levels

Cardiac
HF, including RV syndromes
Acute coronary syndromes
Heart muscle disease, including LVH
Valvular heart disease
Pericardial disease
Atrial fibrillation
Myocarditis
Cardiac surgery
Cardioversion
Toxic-metabolic myocardial insults, including cancer chemotherapy
Noncardiac
Advancing age
Anemia
Renal failure
Pulmonary: obstructive sleep apnea, severe pneumonia
Pulmonary hypertension
Critical illness
Bacterial sepsis
Severe burns

*Modified from Table 8 of the $2013 \mathrm{HF}$ guideline. $9 \mathrm{HF}$, indicates heart failure; LVH, left ventricular hypertrophy; and $\mathrm{RV}$, right ventricular.

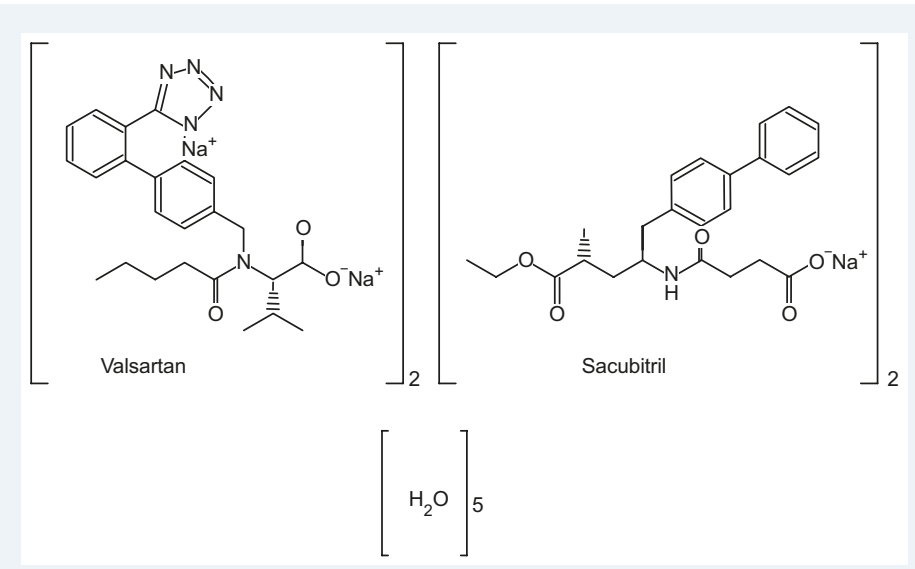

Fig. 1. Molecular formula LCZ696 (sacubitril/valsartan).

without $\mathrm{AH}$ ) leads to $\mathrm{CHF}$ in $60 \%$ of cases [5]. However, even after the diagnosis of coronary HF, stenting was performed only in $7.3 \%$ of patients, and coronary artery bypass grafting (CABG) was performed only in $5.4 \%$. Moreover, in many individuals with HF, acute coronary syndrome or subclinical ischemia are concomitant, and coronary angiography during hospitalization is performed in less than $10 \%$ of patients [6]. In the modern pharmacological arsenal of the Ukrainian physicians the actively used three groups of drugs that modulate the disease / prognosis - ACE inhibitors (Captopril, Enalapril, Fosinopril, Lisinopril, Perindopril, Quinapril, Ramipril, Trandopril) and angiotensin II receptor blockers ARBs (Candesartan, Losartan, Valsartan), $\beta$-blockers (Bisoprolol, Carvedilol), AMR Aldosterone antagonists (Spironolacton, Eplerenone) are currently added by two more - I1 channel inhibitor (Ivabradine) and the ARNI combination drug (sacubitril / valsthartan) .

Currently, in this therapy the focus is shifted to the degradation system of natriuretic peptides (NUP). A number of reasons for an increase in the NUP level are established, and in the first place - chronic heart failure (Table 1).

The system of natriuretic peptides: a bioregulatory mechanism that prevents damage to the cardiovascular system. The enzyme that promotes the degradation of NUP is neutral endopeptidase (NEP) [3]. NEP is widely represented in endothelial and smooth muscle cells, cardiomyocytes, epithelial cells of the renal tubules, as well as in fibroblasts, they are persistently detected in the lung tissue, brain, heart and intestines. NEP is involved in the inactivation of not only NUP, but also such endogenous vasoactive peptides as bradykinin and adrenomedullin, as well as endothelin-1 and angiotensin II (AT II). It has been established that selective inhibitors of NEP prevent the degradation of NUP in vitro and in vivo, as well as increase their biological activity. In addition, NEP inhibitors are able to increase the enzymatic conversion of big endothelin into the active form - endothelin-1 [7].

Neprilizin is a neutral endopeptidase that destroys some endogenous vasoactive peptides, including NUP, bradykinin and adrenomedullin vasodilators [8]. Inhibition of neprilizin increases the level of the above substances, which counteracts vasoconstriction, sodium retention and remodeling. The combined inhibition of the renin-angiotensin system and neprilysin is superior in effectiveness to each of the therapeutic strategies separately according to the results of experimental studies. However, this treatment is associated with the development of severe angioedema.

The use of a new drug, LCZ696 (angiotensin receptor neprilysin inhibitor), containing the necralysin inhibitor sacubitril (AHU377) and the angiotensin II receptor blocker valsartan, according to the results of research, is accompanied by a minimal risk of developing angioedema. The drug - LCZ696 by sight is a white powder, the molecular formula of which is presented below (Fig. 1).

Drug LCZ696 (C24H29N5O3.C24H29NO5.5 / $2 \mathrm{H} 2 \mathrm{O}$. $3 \mathrm{Na}$ ) (sacubitril / valsartan) is a member of a new class of agents called angiotensin receptor neprilizin inhibitor (ARNI), which combine the neprilisin inhibitor and the angiotensin receptor blocker (ARB).

In the course of some studies that included patients with arterial hypertension (AH) or with LVHFpEF the use of LCZ696 provided a more pronounced effect on hemodynamics, as well as on the activity of neurohumoral systems compared to isolated administration of ARB.

Pharmacological effects arising under the influence of sacubitril are associated with the suppression of the activity of neprilysin (neutral endopeptidase (NEP)), which is involved in the metabolism of natriuretic peptide (NUP) and other vasoactive peptides, including bradykinin, adrenomedulline vasodilators, and angiotensin (Ang) II and endothelin-1vasoconstrictors [9].

A key role in the action of sacubitril on the cardiovascular system and kidneys is played by the activation of the NUP system, primarily the atrial natriuretic peptide (ANP) and the brain natriuretic peptide (BNP), which are synthesized predominantly by atrial cardiomyocytes and, to a lesser extent, the ventricles and are secreted into the blood in response to increasing tension in the heart wall. Both peptides realize their effects in target cells 


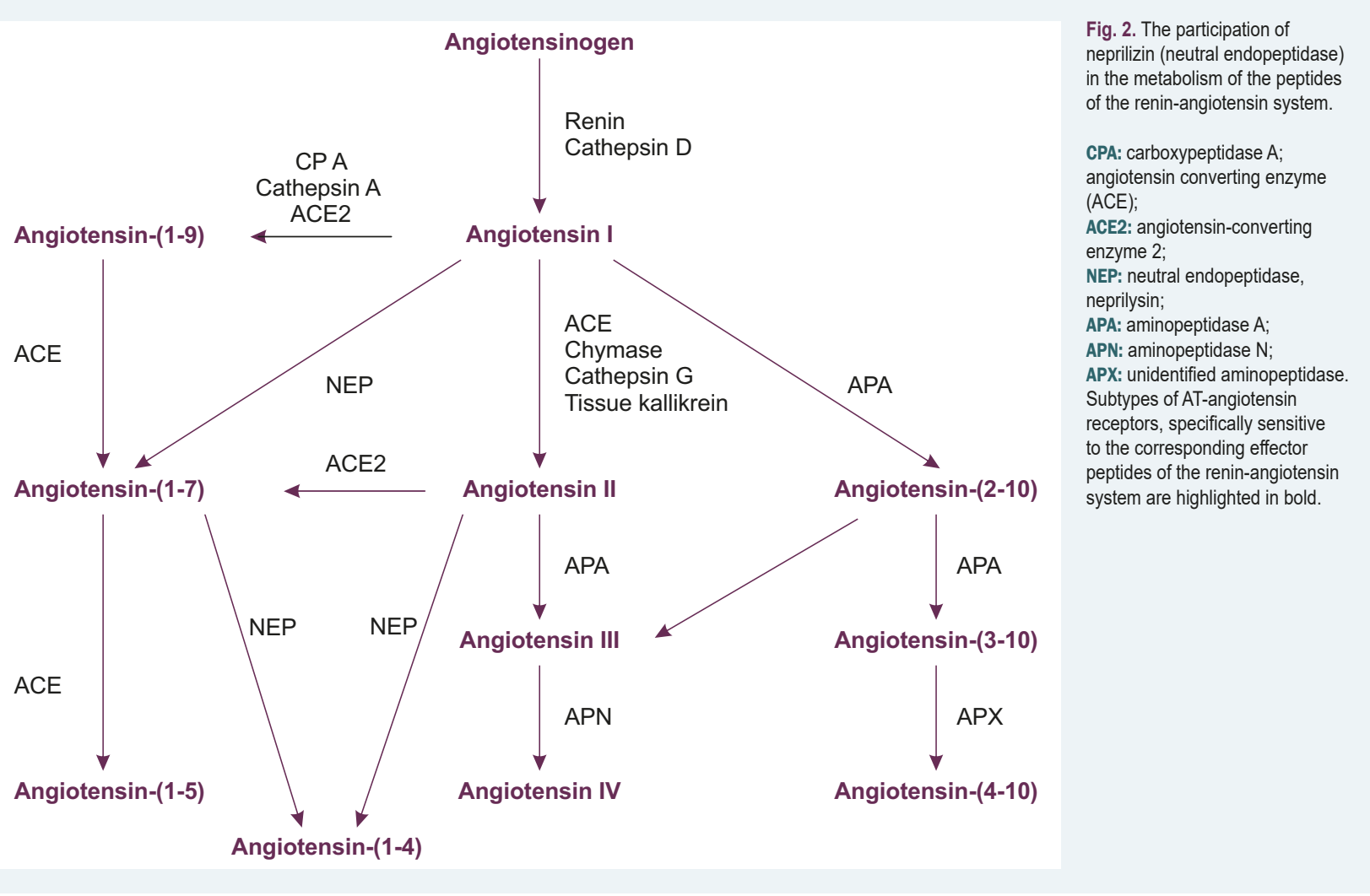

through the excitation of guanylate cyclase A-type receptors (GCR-A), which cause an increase in the activity of transmembrane guanylate cyclase (GC), an increase in the intracellular concentration of cyclic guanosine monophosphate (cGMP) and activation of protein kinase $G$ [10]. The formation of the biological effects of sacubitril and other inhibitors of NEP also involves the C-type natriuretic peptide (CNUP), which is produced not only by vascular endothelium cells, but also by cardiomyocytes, cells of the renal tubules and other organs and tissues. ANP is secreted by cardiomyocytes as an active hormone, and BNP as a prohormone (B-type natriuretic peptide (BNP), a key cardiac hormone in cardiorenal homeostasis, is produced as a 108 amino acid prohormone, proBNP1-108) [11]. CNUP specifically interacts with B-type guanylate cyclase receptors (GCR-B), the excitation of which is ultimately also associated with the activation of the GC / cGMP / protein kinase of the G-signaling pathway [12]. GCR-A and GCR-B mediate all the main effects of NUP in target cells. These are, first of all, the weakening of fibrotic and hypertrophic myocardial damage [13], vasodilation, inhibition of proliferation of smooth muscle cells, antithrombotic and anti-atherosclerotic action in the vessels [13-15], reduction of renin secretion, inhibition of sodium reabsorption in the kidneys and weakening of the sclerosis of the glomeruli, renin and pericanalicular interstitium $[16,17]$. Increased N0 production by endothelial cells, vasodilation, and the antiproliferative effect of all three NUPs also involve C-type receptors that are not associated with GC, but mediate their effects through Gi proteins that inhibit adenylate cyclase activity in target cells, followed by activation of phospholipase C $[18,19]$. Thus, the cardioprotective properties of NUP in HF are extremely important. It has been shown that arterial hypertension $(\mathrm{AH})$ is characterized by the deficit of NUP, leading to natriuresis disorder; in chronic heart failure (CHF), an imbalance of NUP system hormones is also observed $[20,21]$. Therefore, the synthesis of NEP inhibitors is a significant step in the pharmacotherapy of cardiovascular diseases, in particular HF.

Double blockade of neprilysin and AT1 receptors: a new approach to hypertension therapy. Early clinical studies of NEP inhibitors showed that these drugs increase the levels of cGMP and PNP in the blood of patients with essential hypertension and cause a moderate antihypertensive effect, which is most pronounced in the early stages of drug therapy [22]. However, it immediately became apparent that monotherapy with such drugs, despite the activation of NUP, has an adverse effect on the hormonal status of patients, which significantly limits their practical use. First of all, it concerns the activation of circulating and tissue renin-angiotensin-aldosterone systems (RAAS) with increasing blood concentrations of Ang II [22], whose content is largely determined by the activity of NEP, which converts Ang I and Ang II to Ang (1-7), which is a functional antagonist of Ang II (Fig. 2 [23]).

The most well-known drug from the vazopeptidase inhibitors group, omapatrilat, which is not only neprilysin inhibitor, but also an ACE-key enzyme involved in the conversion of Ang I to Ang II, turned out to be more favorable in this respect. However, it turned out that this drug, weakening the effect of the RAAS, causes excessive activation of the effector links of the kallikrein-kinin system due to the simultaneous inhibition of the activity of NEP and ACE (kininase II), which metabolize bradykinin to inactive peptides (Fig. 3). 


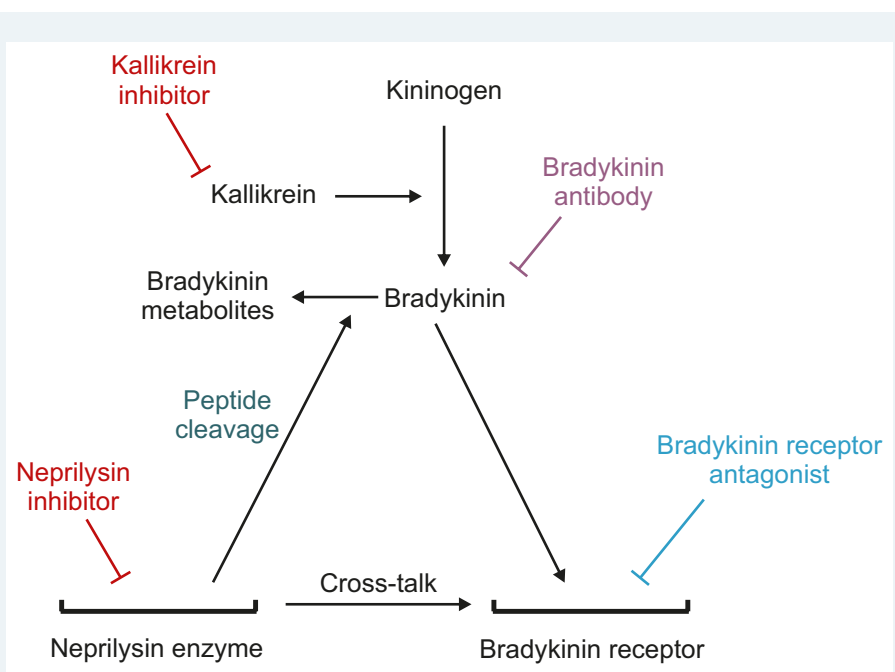

Fig. 3. Participation of neprilizin (neutral endopeptidase) in the metabolism of peptides of the kallikreinkinin system.

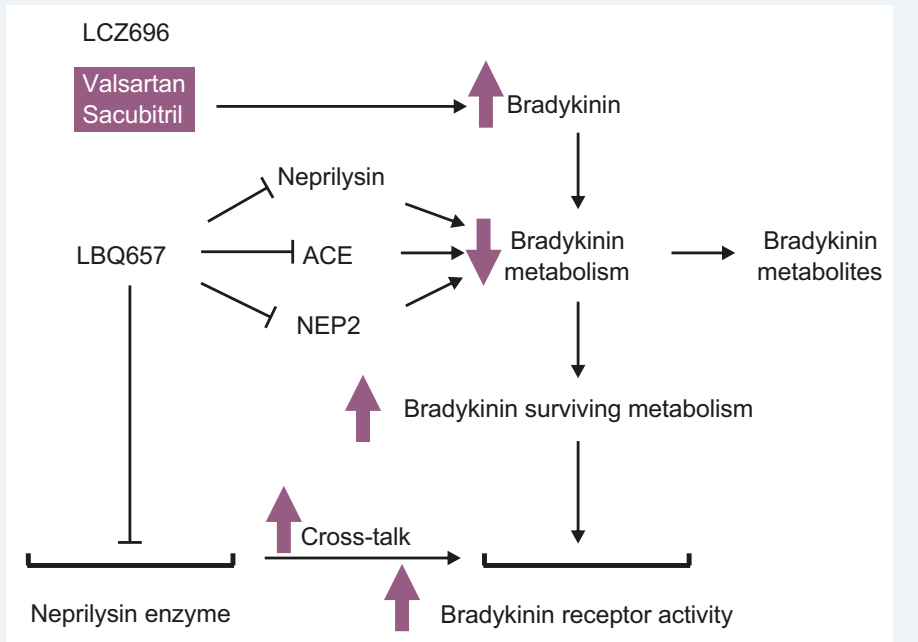

Fig. 4. Potential mechanisms LCZ696 (sacubitril/valsartan).

Angiotensin converting enzyme (ACE); metalloendopeptidase-like 1 (NEP2)

As a result, the risk of angioedema and other complications associated with excessive accumulation of bradykinin significantly increases. According to the OCTAVE study (Omapatrilat and enalapril in patients with hypertension: the Omapatrilat Cardiovascular Treatment vs. Enalapril (OCTAVE) trial), which included 25.302 patients with untreated or uncontrolled hypertension, omapatrilat is superior to ACEI enalapril in the effectiveness of antihypertensive therapy, but is critically inferior to this drug in the incidence of angioedema ( $2.17 \%$ vs. $0.68 \%)$ [24]. The dual inhibitor of neprilisin and the AT1 receptors LCZ696 (sacubitril/valsartan) was created primarily to reduce the risk of angioedema in patients. For this purpose, the drug includes an inhibitor of neprilysin, sacubitril, whose active metabolite, sacubitrilate (LBQ657), does not suppress, in contrast to omapatrilat, aminopeptidase $P$ activity, which participates together with NEP and ACE in the metabolism of bradykinin, and therefore causes a significantly smaller increase in the content of this peptide in tissues $[25,26]$. LBQ657 can also increase bradykinin levels by inhibiting the degradation of bradykinin under the action of neprilizin and, possibly, angiotensin-converting enzyme (ACE) and the homolog of the membrane homolog of neprilizin, like metalloendopeptidase 1 (NEP2). In addition, LBQ657 can enhance the actions mediated by the bradykinin receptor by cross-reacting between the LBQ657 inhibitor complex and the bradykinin receptor.

Another component of LCZ696 ARB valsartan effectively weakens the excess effect of RAAS on target cells associated with the suppression of NEP activity, but, unlike omapatrilat, is not an ACEI and therefore does not inhibit the metabolism processes of bradykinin (Fig. 4).

Due to these properties, LCZ696 is not inferior to omapatrilat in its ability to suppress the activity of RAAS, but it has a weaker effect on the metabolism of bradykinin, which reduces the risk of developing angioedema $[25,26]$. According to PARADIGM-HF study on the comparison of clinical efficacy and safety of using LCZ696 and ACEI of enalapril in 8442 patients with systolic $\mathrm{CHF}$, the detection rate of angioedema for the studied drugs is $0.2 \%$ and $0.1 \%$, respectively [27].

Efficacy of sacubitril / valsartan in patients with both arterial hypertension and heart failure using the example of large randomized studies. As part of the $2^{\text {nd }}$ phase of clinical trials, a number of clinical studies were performed, which enabled us to obtain initial data on its clinical efficacy and safety of use in hypertensive patients, including persons with impaired renal function.

The combination of sacubitril / valsartan has demonstrated efficacy in patients with both $\mathrm{AH}$ and HF. In a large study in patients with $\mathrm{AH}(\mathrm{n}=1328)$, the drug in doses of $200-400 \mathrm{mg}$ showed an advantage in the hypotensive effect over valsartan in doses of $160-320 \mathrm{mg}$ as an additional decrease in blood pressure by $5 / 3$ and $6 / 3 \mathrm{~mm} \mathrm{Hg}$ [28]. The hypotensive effect of the sacubitrile I valsartan combination was accompanied by a more pronounced decrease in pulse BP: by 2.25 and $3.32 \mathrm{~mm}$ $\mathrm{Hg}$ respectively, in doses of 200 and $400 \mathrm{mg}$, which is currently regarded as a positive prognostic factor in influencing the rigidity of the vascular wall and cardiovascular outcomes. Tolerability in patients with $\mathrm{AH}$ was good, no cases of angioedema were noted.

In the PARAMOUNT study, sacubitril / valsartan was compared with the valsartan group in 685 patients with CHF II - IV functional classes (FC) (NYHA) and preserved EF (45\% or more) [29]. Sacubitril / valsartan was titrated to $200 \mathrm{mg} 2$ times a day, and valsartan to $160 \mathrm{mg} 2$ times a day. A new drug provided a significant reduction in the level of prohormone BNP- NT-proBNP (primary endpoint) after 12 weeks. ( $605 \mathrm{pg} / \mathrm{ml}$ versus $835 \mathrm{mg} / \mathrm{ml}$ with valsartan, $P=0.005)$, but not after 36 weeks of therapy $(P=0.20)$, reduced the volume of the left atrium, $F C$ $\mathrm{CHF}$, was well tolerated by patients.

Another study compared the antihypertensive effect of LCZ696 at doses of $100,200,400 \mathrm{mg} /$ day with placebo in 389 patients of Asian origin with grade 1-2 of essential hypertension, which are characterized by increased sensitivity to salt and often reduced RAAS activity. As a result, it was found that LCZ696 in this patient population has a pronounced antihypertensive effect. The difference between the initial systolic blood pressure (SBP) value and its value after 8 weeks of monotherapy in the active 
treatment groups compared with the placebo group was for doses of $100 \mathrm{mg} / \mathrm{day}, 200 \mathrm{mg} /$ day and $400 \mathrm{mg} / \mathrm{day}$, respectively, $-11.86,-12.57$ and $-15.38 \mathrm{~mm} \mathrm{Hg}$ $(P<0.0001)$. Similar data for diastolic blood pressure (DBP) are, respectively, $-7.84,-7.99$ and $-8.76 \mathrm{~mm} \mathrm{Hg}$ $(\mathrm{P}<0.0001)$. All studied doses of LCZ696 also caused an increasing decrease in the 24-hour ambulatory SBP and DBP. No significant side effects, including angioedema, were noted [30].

Five years ago, at the congress of the European Society of Cardiology, the results of the PARADIGM-HF study (Prospective Comparison of ARNI (Angiotensin Receptor-Neprilysin Inhibitor Receptor) with ACEI (Angiotensin-Converting-Enzyme Inhibitor) to Determine Impact on Global Mortality and Morbidity in Heart Failure Trial) were published [27], which have become significant in the treatment of CHF. PARADIGM-HF was an international, multicenter, double- blind, placebo-controlled study with parallel groups (phase III), which studied the efficacy and safety of the sacubitril / valsartan combination in comparison with the popular ACEI enalapril. The study was intended to test the hypothesis that the use of a sacubitril / valsartan combination compared with the use of the ACEI enalapril will more effectively influence the incidence of complications and mortality of patients with CHF.

It should be noted that PARADIGM-HF is the first modern study in the field of HF, which proposed the replacement of one of the main elements of the treatment of such patients, that is, an ACEI. 8436 patients aged 18 years old or older with HF corresponding to II, III or IV FC (NYHA) were included in the PARADIGM-HF study against the background of reduced LVEF ( $40 \%$ or less) (most patients had grade II-III HF). In addition, to be included in the study, the level of BNP should have been at least $150 \mathrm{pg} / \mathrm{ml}$ (or the N-terminal precursor of BNP not less than $600 \mathrm{pg} / \mathrm{ml})$; in the case of hospitalization for worsening of HF within the previous 12 months BNP should have been at least $100 \mathrm{pg} / \mathrm{ml}$ (or N-terminal precursor of BNP not less than $400 \mathrm{pg} / \mathrm{ml}$ ). The study could include patients who took at least during 4 weeks stable dose of beta-blocker and ACEI (or ARB), which was supposed to be equivalent to not less than $10 \mathrm{mg}$ of enalapril. Using the double-blind method of randomization, patients were assigned in a $1: 1$ ratio to the enalapril group (10 mg 2 times a day) or the sacubitril / valsartan combination (200 mg 2 times a day). The primary end point was a combination of death from cardiovascular causes or hospitalization for HF, but the study was designed so that its power was also sufficient to detect differences between the rates of mortality from cardiovascular causes. During the study, data on the development of arterial hypotension, deterioration of renal function, hyperkalemia, cough or angioedema were carefully monitored. The follow-up median was 27 months.

The PARADIGM-HF study was stopped much earlier than the planned date due to the fact that statistically reliable figures were obtained regarding the effect of the investigational drug on the primary endpoints: a decrease in cardiovascular mortality and a combined indicator of "cardiovascular mortality + hospitalization for decompensated HF". At the time of stopping the study, the primary endpoint was recorded in 914 patients $(21.8 \%)$ in the sacubitril / valsartan group and in 1117 patients (26.5\%) in the enalapril group odds ratio (OR) for the LCZ696 group was 0.80; $95 \%$, confidence interval $(\mathrm{Cl}), 0.73$ to $0.87 ; \mathrm{P}<0.001)$. A total of 711 patients (17.0\%) who received sacubitril / valsartan and 835 patients (19.8\%) from the enalapril group died (OR for all-cause death was 0.84; $95 \% \mathrm{Cl}$, 0.76 to $0.93 ; P<0.001)$; of these, $558(13.3 \%)$ and 693 (16.5\%), respectively, persons died of cardiovascular causes (OR 0.80; $95 \% \mathrm{Cl}, 0.71$ to 0.89; $\mathrm{P}<0.001$ ).

Compared with enalapril, the sacubitril / valsartan combination also reduced by $21 \%$ the risk of hospitalization for HF $(P<0.001)$ and reduced the severity of symptoms and physical limitations due to HF $(P=0.001)$.

As for safety, there were more patients with hypotension and non-serious cases of angioedema in the sacubitril / valsartan combination group, but impaired renal function, hyperkalemia and cough were less common than in the group of enalapril. The results were interpreted by researchers as a breakthrough in the field of studying HF. Compared with other tests in connection with HF, patients in PARADIGM-HF received the most optimal therapy for heart failure, with the highest frequency of prescribing beta-blockers (more than $90 \%$ ) and antagonists of mineralocorticoid receptors (AMP) (60\%). As it can be seen from the results of the study, the drug has undeniable clinical efficacy in patients with HF [27].

According to recent data, the NUP system is involved in metabolic regulation: lipid oxidation, adipocyte formation and differentiation, adiponectin activation, insulin secretion, and carbohydrate tolerance, which can provide protection against the development of the metabolic syndrome [31].

During the first year of observation, $\mathrm{HbA} 1 \mathrm{c}$ levels decreased by $0.16 \%$ in the enalapril group and by $0.26 \%$ in the sacubitril / valsartan group (intergroup reduction of $0.13 \%, 95 \% \mathrm{Cl} 0.05-0.22, \mathrm{P}=0.0023$ ). The $\mathrm{HbA} 1 \mathrm{c}$ level in the sacubitril / valsartan group was significantly lower than in the enalapril group during the 3-year observation period (intergroup reduction was $0.14 \%, 95 \% \mathrm{Cl}$ $0.06-0.23, P=0.0055)$. The first use of insulin was $29 \%$ less frequent in patients treated with sacubitril/valsartan (114 (7\%) patients) compared with patients treated with enalapril (153 (10 \%) (OR 0.71; $95 \%$ Cl 0.56 - 0.90; $P=0.0052)$. Similarly in the sacubitril / valsartan group fewer patients started taking oral hypoglycemic drugs (OR 0.77; Cl $0.58-1.02 ; \mathrm{P}=0.073$ ). Therefore, in the PARADIGM-HF study, patients with DM and HF with reduced $E F$ who received sacubitril/valsartan had a more pronounced long-term decrease in $\mathrm{HbA} 1 \mathrm{c}$ compared to patients treated with enalapril. These data suggest that the combination of sacubitril / valsartan may enhance glycemic control in patients with diabetes mellitus (DM) and $\mathrm{HF}$ with reduced EF [32].

When ingested, the sacubitril / valsartan complex breaks up into sacubitril, which is then metabolized to form the metabolite LBQ657, and valsartan; the concentrations of these substances in the blood plasma reach a maximum after $0.5 \mathrm{~h}, 3.0 \mathrm{~h}$ and $1.5 \mathrm{~h}$, respectively [33]. The use of the drug does not depend on meal times. The complex of sacubitril and valsartan largely binds with plasma proteins (94-97\%). LBQ657 to a small extent penetrates the blood-brain barrier (BBB) $(0.28 \%)$. LBQ657 is not 
further metabolized significantly. Valsartan is metabolized to a small extent. After ingestion, $52-68 \%$ of sacubitril (mainly in the form of LBQ657) and about $13 \%$ of valsartan and its metabolites are excreted by the kidneys, $37-48 \%$ of sacubitril (mainly in the form of LBQ657) and $86 \%$ of valsartan and its metabolites are excreted through the intestines. Considering the pharmacokinetic data in patients over 65 years old, dose adjustment is not required. Patients with impaired renal function of mild and moderate degree do not need to adjust the dose. In case of severe disorder of renal function, sacubitril/ valsartan is used with caution. In patients with impaired liver function, mild or moderate, including patients with obstruction of the biliary tract, the dose should not be adjusted. For severe disorders of liver function, the drug is not recommended.

Based on the results of the PARADIGM-HF study in 2015, the sacubitril / valsartan combination was approved by the US Food and Drug Administration (FDA) and the European Medicines Agency for the Treatment of Patients Suffering from HFrEF II-IV FC by NYHA, and included in the recommendations of the 2016 European Society of Cardiology as a means of treating patients with CHF [34-36].

These TRANSITION studies were presented at a congress of the European Society of Cardiology in Munich, Germany. These data showed that the drug sacubitril / valsartan has a high safety profile with an early administration to the widest range of patients with heart failure with a reduced LVEF, who were stabilized after an episode of acute decompensated heart failure. Among the patients participating in the study, there were patients who had not previously taken sacubitril / valsartan or other basic CHF therapy, as well as patients with experience in treating with these drugs.

TRANSITION (NCT02661217) is a randomized, multicenter, open, non-cross-sectional phase IV study to evaluate the safety and tolerability of sacubitril/valsartan in 1006 patients with HFrEF in 156 clinics around the world who were stabilized after an acute decompensated heart failure episode with the onset of sacubitril /valsartan therapy in the hospital or immediately after discharge from the hospital. Patients were divided into groups according to the treatment they received before hospitalization: those who received angiotensin-converting enzyme inhibitors (ACEI) or angiotensin receptor antagonists (ARA), as well as those who did not have experience of treatment with ACEI / ARA. After screening and randomization into sacubitril/valsartan treatment groups, the study implied a 10-week therapeutic period and a follow-up phase of 16 weeks. The primary and secondary endpoints were selected: the number of patients who reached the target dose of sacubitril / valsartan 200 mg 2 times a day at week 10 (regardless of the possible temporary discontinuation of therapy or dose reduction in the past), and the number of patients taking the drug in the dosage $100 \mathrm{mg}$ or $200 \mathrm{mg}$ for at least 2 weeks to the expiration of 10 weeks after randomization, respectively. The study protocol took into account the needs of practicing cardiologists and enabled the researchers to choose the appropriate initial dose of sacubitril / valsartan and adjust it according to clinical circumstances, taking into account the differences between clinics and medical institutions in different countries [37].

During the TRANSITION study, the safety and tolerability of sacubitril / valsartan was evaluated among patients with HFrEF after an episode of acute decompensated heart failure, followed by stabilization. The patients were randomly divided into two groups - the first received sacubitril / valsartan already in the hospital (before discharge), the second - in a short time after discharge from the hospital. At the time of the expiry of 10 weeks, more than $86 \%$ of patients continuously took sacubitril/valsartan for 2 weeks or longer, and about half of the patients reached the primary endpoint - reaching a therapeutic dose of sacubitril/valsartan $200 \mathrm{mg} 2$ times a day, which was observed in both groups. The number of patients who reached the primary and secondary endpoints was similar in both groups. The incidence of side effects and discontinuation of taking sacubitril/valsartan due to side effects was also similar between groups among hospitalized and outpatient patients.

However, a number of questions now remain, the answers to which need to be obtained when conducting new clinical trials. The questions are related to the lack of data on the use of the drug in patients initially not receiving therapy with ACEI or ARA II; there is no data on the use of the drug with patients with decompensated HF; with patients with HF and acute myocardial infarction; with patients with LVHFpEF.

We hope that these issues will be resolved in already conducted HFNLIFE (Entresto TM In Advanced Heart Failure), PARADISE-MI (Prospective ARNI vs ACE Inhibitor Trial for Determine Superiority in Mitigation), PARAGON-HF clinical studies and, possibly, will open new capabilities of sacubitril / valsartan complex in HF pharmacotherapy [37].

\section{Conclusions}

1. The conducted clinical studies, and in particular PARADIGM-HF, TRANSITION demonstrated the superiority of the new combination compared with enalapril. It was found that the combination of sacubitril / valsartan more effectively than enalapril reduces the risk of total cardiovascular death and hospitalization in patients with CHF and reduced LVEF, which meets fairly strict inclusion and exclusion criteria. The main positive effects of sacubitril and valsartan in patients with $\mathrm{CHF}$ are associated with an increase in the amount of the natriuretic peptide and the simultaneous suppression by valsartan of the negative effects of angiotensin II. The result of this action is vasodilatation, an increase in natriuresis and diuresis, a decrease in the secretion of renin and aldosterone, the suppression of sympathetic activity, and the slowing of myocardial remodeling.

2. The indication for the use of the sakubitril / valsartan complex is CHF (II-IV FC according to the NYHA classification) in patients with systolic dysfunction in order to reduce the risk of cardiovascular mortality and hospitalization for HF.

Conflicts of interest: authors have no conflict of interest to declare. Конфлікт інтересів: віАсутній. 
Надійшла Ао редакції / Received: 31.05.2019

Після Аоопрацювання / Revised: 06.08.2019

Прийнято Ао Аруку / Accepted: 13.08.2019

\section{Information about authors:}

Ashcheulova T. V., MD, PhD, DSc, Professor, Head of

the Department of Propedeutics to Internal Medicine, Basis

of Bioethics and Biosafety, Kharkiv National Medical University,

Ukraine.

ORCID ID: 0000-0002-8860-652x

Kompaniiets K. M., MD, PhD, DSc, Professor of the Department of Propedeutics of Internal Medicine 1, Basis of Bioethics and Biosafety, Kharkiv National Medical University, Ukraine. ORCID ID: 0000-0001-7653-9596

Herasimchuk N. M., MD, PhD, Associate Professor of the Department of Propedeutics to Internal Medicine 1, Basis of Bioethics and Biosafety, Kharkiv National Medical University, Ukraine.

ORCID ID: 0000-0002-3172-6491

\section{Відомості про авторів:}

Ащеулова Т. В., А-р меА. наук, професор, зав. каф. пропедевтики внутрішньої медицини № 1, основ біоетики та біобезпеки, Харківський національний медичний університет, Україна. Компанієць К. М., А-р меА. наук, професор, каф. пропедевтики внутрішньої меАицини № 1, основ біоетики та біобезпеки, Харківський національний медичний університет, Україна. Герасимчук Н. М., канА. меА. наук, доцент каф. пропедевтики внутрішньої медицини № 1, основ біоетики та біобезпеки, Харківський національний медичний університет, Україна.

\section{Сведения об авторах:}

Ащеулова Т. В., А-р меА. наук, профессор,

зав. каф. пропедевтики внутренней медицины № 1, основ биоэтики и биобезопасности, Харьковский национальный медицинский университет, Украина.

Компаниец К. Н., А-р меА. наук, профессор, каф. пропедевтики внутренней медицины № 1, основ биоэтики и

биобезопасности, Харьковский национальный меАицинский университет, Украина.

Герасимчук Н. Н., канА. меА. наук, Аоцент каф. пропедевтики внутренней медицины № 1, основ биоэтики и биобезопасности, Харьковский национальный медицинский университет, Украина.

\section{References}

[1] Yancy, C. W., Jessup, M., Bozkurt, B., Butler, J., Casey, D. E., Colvin, M. M., ... Westlake, C. (2016). 2016 ACC/AHA/HFSA focused update on new pharmacological therapy for heart failure: An update of the 2013 ACCF/AHA guideline for the management of heart failure: A report of the American College of Cardiology/American heart association Task Force on Clinical practice guidelines and the heart failure society of America. Journal of the American College of Cardiology, 68(13), 1476-1488. https://doi.org/10.1016/j.jacc.2016.05.011

[2] Molchanov, D. (2016). VI nauchno-prakticheskaya konferentsiya Ukrainskoy Assotsiatsii spetsialistov po serdechnoy nedostatochnosti: obzor materialov [VI scientific-practical conference of the Ukrainian Association of Specialists in Heart Failure: a review of materials]. Sertseva nedostatnist. 2, 60-71. [in Russian].

[3] Reynolds, K., Butler, M. G., Kimes, T. M., Rosales, A. G., Chan, W., \& Nichols, G. A. (2015). Relation of Acute Heart Failure Hospital Length of Stay to Subsequent Readmission and All-Cause Mortality. American Journal of Cardiology, 116(3), 400-405. https://doi.org/10.1016/j. amjcard.2015.04.052

[4] Gordin, J. S., \& Fonarow, G. C. (2016). New medications for heart failure. Trends in Cardiovascular Medicine, 26(6), 485-492. https://doi. org/10.1016/j.tcm.2016.02.008

[5] Voronkov, L. H. (2012). Patsiient iz HSN v Ukraini : analiz danykh populiatsii patsiientiv, obstezhenykh u ramkakh pershoho natsionalnoho zrizovoho doslidzhennia UNIVERS [A patient with CHF in Ukraine: an analysis of the data of the population of patients surveyed in the framework of the first national study UNIVERS]. Sertseva nedostatnist, 2, 6-13. [in Ukrainian].

[6] Ambrosy, A. P., Fonarow, G. C., Butler, J., Chioncel, O., Greene, S. J., Vaduganathan, M., ... Gheorghiade, M. (2014). The Global Health and Economic Burden of Hospitalizations for Heart Failure. Journal of the American College of Cardiology, 63(12), 1123-1133. https://doi. org/10.1016/j.jacc.2013.11.053

[7] Kentsch, M., \& Otter, W. (1999). Novel neurohormonal modulators in cardiovascular disorders. The therapeutic potential of endopeptidase inhibitors. Drugs in R\&D. https://doi.org/10.2165/00126839199901040-00011

[8] Dalzell, J. R., Seed, A., Berry, C., Whelan, C. J., Petrie, M. C., Padmanabhan, N., . . . McMurray J. V. (2014). Effects of Neutral Endopeptidase (Neprilysin) Inhibition on the Response to Other Vasoactive Peptides in Small Human Resistance Arteries: Studies with Thiorphan and Omapatrilat. Cardiovascular Therapeutics, 32(1), 13-18. https:// doi.org/10.1111/1755-5922.12053

[9] Wong P. C. Y., Guo J. \& Zhang A. (2017). The renal and cardiovascular effects of natriuretic peptides. Advances in Physiology Education, 41(2), 179-185. https://doi.org/10.1152/advan.00177.2016

[10] Kerkela, R., Ulvila, J., \& Magga, J. (2015). Natriuretic Peptides in the Regulation of Cardiovascular Physiology and Metabolic Events. Journal of the American Heart Association, 4(10). https://doi. org/10.1161/jaha.115.002423

[11] Tonne, J. M., Campbell, J. M., Cataliotti, A., Ohmine, S., Thatava, T., Sakuma, T., ... Ikeda, Y. (2011). Secretion of Glycosylated Pro-B-Type Natriuretic Peptide from Normal Cardiomyocytes. Clinical Chemistry, 57(6), 864-873. https://doi.org/10.1373/clinchem.2010.157438

[12] Kuhn, M. (2016). Molecular physiology of membrane guanylyl cyclase receptors. Physiological Reviews, 96(2), 751-804. https://doi. org/10.1152/physrev.00022.2015

[13] Santhekadur, P. K., Kumar, D. P., Seneshaw, M., Mirshahi, F., \& Sanyal, A. J. (2017). The multifaceted role of natriuretic peptides in metabolic syndrome. Biomedicine \& Pharmacotherapy, 92, 826-835. https://doi. org/10.1016/j.biopha.2017.05.136

[14] Moyes, A. J., Khambata, R. S., Villar, I., Bubb, K. J., Baliga, R. S., Lumsden, N. G., . . Hobbs, A. J. (2014). Endothelial C-type natriuretic peptide maintains vascular homeostasis. Journal of Clinical Investigation, 124(9), 4039-4051. https://doi.org/10.1172/jci74281

[15] Ichiki, T., \& Burnett, J. C. (2017). Atrial Natriuretic Peptide - Old But New Therapeutic in Cardiovascular Diseases. Circulation Journal, 81(7), 913-919. https://doi.org/10.1253/circj.CJ-17-0499

[16] Theilig, F., \& Wu, Q. Y. (2015). ANP-induced signaling cascade and its implications in renal pathophysiology. American Journal of Physiology-Renal Physiology, 308(10), F1047-F1055. https://doi.org/10.1152/ ajprenal.00164.2014

[17] Yoshihara, F., Tokudome, T., Kishimoto, I., Otani, K., Kuwabara, A. Horio, T., ... Kangawa, K. (2015). Aggravated renal tubular damage and interstitial fibrosis in mice lacking guanylyl cyclase-A (GC-A), a receptor for atrial and B-type natriuretic peptides. Clinical and Experimental Nephrology, 19(2), 197-207. https://doi.org/10.1007/ s10157-014-0982-1

[18] Buttgereit, J., Shanks, J., Li, D., Hao, G., Athwal, A., Langenickel, T. H., ... Herring, N. (2016). C-type natriuretic peptide and natriuretic peptide receptor $B$ signalling inhibits cardiac sympathetic neurotransmission and autonomic function. Cardiovascular Research, 112(3), 637-644. https://doi.org/10.1093/cvr/cvw184

[19] Volpe, M., Rubattu, S., \& Burnett, J. (2014). Natriuretic peptides in cardiovascular diseases: current use and perspectives. European Heart Journal, 35(7), 419-+. https://doi.org/10.1093/eurheartj/eht466

[20] Holditch, S. J., Schreiber, C. A., Nini, R., Tonne, J. M., Peng, K. W., Geurts, A., . . Ikeda, Y. (2015). B-Type Natriuretic Peptide Deletion Leads to Progressive Hypertension, Associated Organ Damage, and Reduced Survival Novel Model for Human Hypertension. Hypertension, 66(1), 199-210. https://doi.org/10.1161/hypertensionaha.115.05610

[21] Jaffe, A. S., Apple, F. S., Mebazaa, A., \& Vodovar, N. (2015). Unraveling $\mathrm{N}$-Terminal Pro-B-Type Natriuretic Peptide: Another Piece to a Very Complex Puzzle in Heart Failure Patients. Clinical Chemistry, 61(8), 1016-1018. https://doi.org/10.1373/clinchem.2015.243626

[22] Richards, A. M., Wittert, G. A., Crozier, I. G., Espiner, E. A., Yandle, T. G., Ikram, H., \& Frampton, C. (1993). Chronic inhibition of endopeptidase 24.11 in essential-hypertension - evidence for enhanced atrial-natriuretic-peptide and angiotensin-II. Journal of Hypertension, 11(4), 407-416. https://doi.org/10.1097/00004872-199304000-00011

[23] Kuzmin, O. B. Zhezha, V. V., Belyanin, V. V., Landar, L. N. (2016). Glomerulyarnaya gipertenziya: molekulyarnye mekhanizmy povrezhdeniya podotsitov i mezangial'nykh kletok : (obzor) [Glomerular hypertension: molecular mechanisms of podocyte and mesangial cells damage]. Nefrologiya, 20(4), 39-45. [in Russian].

[24] Kostis, O. B., Packer, M., Black, H. R., Schmieder, R., Henry, D., \& Levy, E. (2004). Omapatrilat and enalapril in patients with hypertension: The omapatrilat cardiovascular treatment vs. enalapril (OCTAVE) trial. American Journal of Hypertension, 17(2), 103-111. https://doi. org/10.1016/j.amjhyper.2003.09.014

[25] Gu, J., Noe, A., Chandra, P., Al-Fayoumi, S., Ligueros-Saylan, M., Sarangapani, R., .. . Dole, W. P. (2010). Pharmacokinetics and Pharmacodynamics of LCZ696, a Novel Dual-Acting Angiotensin Recep- 
tor-Neprilysin Inhibitor (ARNi). Journal of Clinical Pharmacology, 50(4), 401-414. https://doi.org/10.1177/0091270009343932

[26] Kusaka, H., Sueta, D., Koibuchi, N., Hasegawa, Y., Nakagawa, T. Lin, B. W., . . Kim-Mitsuyama, S. (2015). LCZ696, Angiotensin II Receptor-Neprilysin Inhibitor, Ameliorates High-Salt-Induced Hypertension and Cardiovascular Injury More Than Valsartan Alone. American Journal of Hypertension, 28(12), 1409-1417. https://doi. org/10.1093/ajh/hpv015

[27] McMurray, J. J. V., Packer, M., Desai, A. S., Gong, J. J., Lefkowitz, M. P., Rizkala, A. R., . . Comm, P. -H. I. (2014). Angiotensin-Neprilysin Inhibition versus Enalapril in Heart Failure. New England Journal of Medicine, 371(11), 993-1004. https://doi.org/10.1056/NEJMoa1409077

[28] Ruilope, L. M., Dukat, A., Bohm, M., Lacourciere, Y., Gong, J. J., \& Lefkowitz, M. P. (2010). Blood-pressure reduction with LCZ696, a novel dual-acting inhibitor of the angiotensin II receptor and neprilysin: a randomised, double-blind, placebo-controlled, active comparator study. Lancet, 375(9722), 1255-1266. https://doi.org/10.1016/s01406736(09)61966-8

[29] Solomon, S. D., Zile, M., Pieske, B., Voors, A. A., Shah, A., Kraigher-Krainer, E., . . . Prospective Comparison, A. A.R.B.M. (2012). The angiotensin receptor neprilysin inhibitor LCZ696 in heart failure with preserved ejection fraction: a phase 2 double-blind randomised controlled trial. Lancet, 380(9851), 1387-1395. https://doi.org/10.1016/ s0140-6736(12)61227-6

[30] Kario, K., Sun, N. L., Chiang, F. T., Supasyndh, O., Baek, S. H., Inubushi-Molessa, A., . . . Zhang, J. (2014). Efficacy and Safety of LCZ696, a First-in-Class Angiotensin Receptor Neprilysin Inhibitor in Asian Patients With Hypertension. Hypertension, 63(4), 698-705. https://doi.org/10.1161/hypertensionaha.113.02002

[31] Volpe, M., Rubattu, S., \& Battistoni, A. (2019). ARNi: A Novel Approach to Counteract Cardiovascular Diseases. International Journal of Molecular Sciences, 20(9). https://doi.org/10.3390/ijms20092092

[32] Seferovic, J. P., Claggett, B., Seidelmann, S. B., Seely, E. W., Packer, M., Zile, M. R., . . . Solomon, S. D. (2017). Effect of sacubitril/ valsartan versus enalapril on glycaemic control in patients with heart failure and diabetes: a post-hoc analysis from the PARADIGM-HF trial. Lancet Diabetes \& Endocrinology, 5(5), 333-340. https://doi. org/10.1016/s2213-8587(17)30087-6

[33] Menendez, J. T. (2016). The Mechanism of Action of LCZ696. Cardiac Failure Review. 2(1), 40-46. https://doi.org/10.15420/cfr.2016:1:1

[34] Ponikowski, P., Voors, A. A., Anker, S. D., Bueno, H., Cleland, J. G. F., Coats, A. J. S., . . . Guazzi, M. (2016). 2016 ESC Guidelines for the diagnosis and treatment of acute and chronic heart failure: The Task Force for the diagnosis and treatment of acute and chronic heart failure of the European Society of Cardiology (ESC). Developed with the special contribution of the Heart Failure Association (HFA) of the ESC. European Journal of Heart Failure, 18(8), 891-975. https:// doi.org/10.1002/ejhf.592

[35] New medicine to treat heart failure recommended for approval. (2015 September). Retrieved from https://www.ema.europa.eu/en/news/ new-medicine-treat-heart-failure-recommended-approval

[36] Jhund, P. S., \& McMurray, J. J. V. (2016). The neprilysin pathway in heart failure: a review and guide on the use of sacubitril/valsartan. Heart, 102(17), 1342-1347. https://doi.org/10.1136/heartjnl-2014-306775

[37] Wachter, R., Senni, M., Belohlavek, J., Butylin, D., Noe, A., Pascual-Figal, D., \& Investigators, T. S. (2018). Initiation of sacubitril/valsartan in hospitalized patients with heart failure with reduced ejection fraction after hemodynamic stabilization: primary results of the TRANSITION study. European Heart Journal, 39, 167-167. https://doi.org/10.1093/ eurheartj/ehy564.p886 